Article

\title{
Prospects for Improving Gravity-Fed Surface Irrigation Systems in Mediterranean European Contexts
} Daniele Masseroni ${ }^{1, *}$, Sandra Ricart ${ }^{2}$, Francisco Ramirez de Cartagena ${ }^{3}$, Joaquim Monserrat $^{4}{ }^{,}$
José Manuel Gonçalves ${ }^{5}$, Isabel de Lima ${ }^{6}$, Arianna Facchi ${ }^{1}$, Guido Sali ${ }^{1}{ }_{\text {and Claudio Gandolfi }}{ }^{1}$

1 Department of Agricultural and Environmental Sciences (DiSAA), University of Milan, Via Celoria 2, 20133 Milano, Italy; arianna.facchi@unimi.it (A.F.); guido.sali@unimi.it (G.S.);

claudio.gandolfi@unimi.it (C.G.)

2 Department of Geography, University of Girona, Plaça Ferrater Mora 1, 17071 Girona, Spain; sandra.ricart@udg.edu

3 Department of Chemical and Agricultural Engineering and Technology, University of Girona, Campus Montilivi, 17071 Girona, Spain; francisco.ramirez@udg.edu

4 Department of Agroforestry Engineering, University of Lleida, Alcalde Rovira Roure 191, 25198 Lleida, Spain; monserrat@eagrof.udl.cat

5 College of Agriculture, Polytechnic of Coimbra, 3015-316 Coimbra, Portugal; jmmg@esac.pt

6 Marine and Environmental Sciences Centre (MARE), Department of Civil Engineering, University of Coimbra, Campus 2, Rua Luis Reis Santos, 3030-788 Coimbra, Portugal; iplima@uc.pt

* Correspondence: daniele.masseroni@unimi.it; Tel.: +39-02-503-16903; Fax: +39-02-503-16900

Academic Editors: Tim Hess and Jerry Knox

Received: 16 November 2016; Accepted: 23 December 2016; Published: 1 January 2017

Abstract: Traditionally, most irrigation practices in Southern Europe have been based on gravity-fed surface irrigation systems. Currently, these systems remain a relevant typology in the European Union (EU) member states of the Mediterranean areas, where it is often the only sustainable method for farmers due to the small size of agricultural holdings, their reduced capacity and readiness to invest and the low ratio between yield profits and irrigation costs. In the last several years, in response to European and national directives, surface irrigation has garnered increasing attention at the political and bureaucratic levels due to frequent criticisms of its postulated low efficiency and high water wastage. However, these systems commonly provide a number of ecosystem services and nature-based solutions that increase the positive externalities in different rural socio-ecological contexts and often have the potential to extend these services and provide solutions that are compatible with economical sustainability. This study aims to discuss the prospects for new practices and for the rehabilitation and modernization of the gravity-fed surface irrigation systems in EU Mediterranean areas to enhance water efficiency, thus gaining both economic advantages and environmental benefits. The difficulties, stimuli for improvements and peculiarities of the irrigation water management of four rural environments located in Italy, Spain and Portugal were analyzed and compared to the current state of the gravity-fed surface irrigation systems with hypothetical future improvements achievable by innovative technologies and practices. In these different case studies, the current gravity-fed surface irrigation systems have an obsolete regulatory structure; water-use efficiency is not a driving criterion for the management of the conveyance and distribution canal network, and farmers are not yet adequately encouraged to adopt more efficient gravity-fed irrigation practices. A continuous knowledge exchange is thus necessary for the interaction of all irrigation water managers and farmers to improve their eco-efficiency and to preserve and promote their cultural heritage across the entire water supply and delivery chains. We argue that the best way forward will require precisely targeted rehabilitation measures of gravity-fed surface irrigation systems based on the integrated use of decision support services, gate automation, remote and feedback controls and real-time flow optimization. 
Keywords: gravity-fed surface irrigation systems; irrigation network; irrigation policy; water multi-functionality; irrigated agriculture sustainability

\section{Introduction}

Irrigation practices in Europe have traditionally consisted of gravity-fed surface irrigation systems. In these cases, the water is conveyed from surface sources (primarily rivers or reservoirs, both natural and artificial) and is distributed to individual fields through a network of canals of different sizes, relying on gravity as the driving force. In sizeable areas of the southern Member States, especially in Catalonia, Northern Italy and Portugal, gravity-fed surface irrigation remains the dominant form of irrigation, being used in $51 \%, 70 \%$ and $63 \%$ of farms, respectively [1]. The main cultivated crops are cereals, particularly maize and rice, which require approximately two to three times the amount of water compared with other extensive crops [2]. The utilized agricultural area (UAA) in these states accounts for approximately $40 \%$ of the total land area, resulting in an average size of 16.1 ha per agricultural holding. The mean field size is approximately $5 \mathrm{ha}$, with a high level of fragmentation that affects the labor decisions of farmers, and consequently, the performances of farms [3].

Since the Renaissance, the hectic development of a dense network of gravity-fed surface irrigation canals for water delivery to single agricultural fields has occurred, mainly due to the high level of land fragmentation and small field sizes [4]. However, the lack of coordination among water users caused redundancy in these canals, leading to a chaotic structure, complex layout, and a lack of a specific hierarchy [5]. Nevertheless, the complex system of reservoirs, rivers, and irrigation canals that is common in rural Southern European territories is an emblematic model of hydraulic infrastructures, and although it can be perceived as obsolete, in general, it is operationally efficient and helps to maintain the good environmental status of the natural resources in several ways [6-8]. The majority of the irrigation canals are unlined and resemble small natural rivers rather than artificial infrastructures that support agriculture; this facilitates their integration into the landscape and gives them an environmental value as well as a cultural heritage [9-11].

As the largest user of fresh water, agriculture sits at the interface between the environment and society, and any improvements in irrigation water management need to consider its multifunctional nature [12-14]. The history of irrigation in these territories is inseparable from that of land management, and every change in the gravity-fed surface irrigation systems, even in a small area, can affect the hydrologic balance and agro-ecosystem characteristics on a large scale $[15,16]$. The neoclassical concept of irrigation efficiency (based on supply efficiency only) has been replaced by a modern formulation called "effective efficiency" of irrigation [17-19], which includes the abovementioned hydrological issues as well as environmental and ecological interactions.

In light of these considerations, it is important to promote monitoring activities for accurately quantifying agro-environmental variables from climatic parameters to evaluate the flow into the irrigation canals (from the main canals to distribution ditches). In fact, the lack of data about the flow in rural canals is a central issue in planning and decision-making processes for the development of suitable water resource management strategies at the basin level [20-23]. This problem could also be exacerbated by an increase in the total global water withdrawals for irrigation, which are projected to increase by $10 \%$ by 2050 [24]. Strong competition between the irrigation water resources, energy, agriculture and food are looming, with unpredictable impacts on livelihoods and the environment [25]. Thus, cross-sectoral actions such as those oriented by the Water-Energy-Food Security nexus [26] or Water-Food-Energy-Ecosystem nexus [27] will also affect future irrigation system projects and water allocations to promote more efficient water distribution and prevent waste.

This study analyzed the characteristics and the importance of the gravity-fed surface irrigation systems in four irrigation districts belonging to three states in southern Europe (the Est Ticino-Villoresi districts in Italy, the Baix Ter and the Urgell districts in Spain, and the Lis Valley district in Portugal). 
The prospects and difficulties around the possibility of improving the irrigation throughout these systems as well as their management and governance are compared and discussed. We argue that this study may form the basis for a discussion on the recommended improvements on gravity-fed surface irrigation systems that would preserve their agricultural heritage and continue to provide environmental benefits.

\section{European Policies and Guidelines}

Gravity-fed surface irrigation systems remain the most common type of infrastructure for crop and pasture irrigation worldwide due to their low cost and low energy requirements [1]. However, these systems often use very high amounts of water to satisfy the irrigation requirements of the crops and are thought to be inherently inefficient [28]. Thus, in response to increasing conflicts among different water users and the need to safeguard the availability of water resources, many important policies have been introduced to reduce water wastage in agriculture settings and to promote the transformation of traditional irrigation systems into pressurized ones, which are often based on drip irrigation [29]. In Spain, with the modernization of the irrigation systems over the period of 2005-2015, the area under pressurized irrigation has increased by approximately 563,000 ha $(87 \%$ with drip irrigation), while surface irrigation has been reduced to approximately 215,000 ha [30]. From 1990 to 2007 , these policies have helped achieve an estimated increase of $15 \%$ in irrigation water use efficiency, but this came with an increase in the energy consumption per hectare of irrigated land by a factor of 8 and of the energy consumption per cubic meter of water by a factor of 10 [31]. This, in combination with the noticeable increase in the electricity price in recent years, has produced a certain alarm. In this context, some new pressurized irrigation facilities built with modern technology are not functioning due to high energy costs that render them non-profitable. Alarcon et al. [32] warns that some actions aimed at increasing irrigation efficiency may incur meager savings of water at a high cost and that many environmental impacts on the landscape are often underestimated.

The management of water resources is a particularly challenging and difficult task, in which complexities inherent to the hydrological cycle and biological systems are combined with the multiple perspectives, needs, values and concerns associated with the use of water for human activities [33]. Accordingly, the need for a more sustainable and integrated approach to manage water resources in Europe is reflected not only in water-related legislation but also in social policies [34,35]. The Water Framework Directive (WFD) and more recent policies that are closely related to the EU 2020 strategies highlight the fact that improving water resource management for irrigation is one of the primary regional challenges, with strong socio-economic implications [36]. Indeed, Europe recognizes that there is an urgent need to enhance the knowledge of irrigation consumption and to develop systems for increasing the delivery efficiency and regulating water flow at the field and irrigation canal scales, respectively (DM 15/07/2015 No. 213, 2015). EU policy frameworks place great expectations on new technologies to improve water efficiency [37]. The European Commission emphasizes that technological innovation in the field of irrigation will be an increasingly important factor contributing to the competitiveness of small and medium enterprises that operate in this sector [38]. According to the European Parliament, solutions should be found in "clean technologies" that facilitate the efficient use of water without requiring non-renewable energies [39]. As reported in [40], water-efficient irrigation, irrigation on demand, and irrigation using brackish water are technologies that will enable the better management of scarce freshwater resources [41]. Technological developments for irrigation processes will encompass sensors and communication devices, intelligent watering systems and high-efficiency delivery mechanisms for water and nutrients as well as a method for incorporating all of these elements into irrigation "packages" [36]. Similarly, irrigation water efficiency can be enhanced by improvements in the use of current installations and / or by adopting new equipment that is economically supported by funds from the European Agricultural Fund for Rural Development [42]. These funds are specifically intended to be used for the development of more efficient irrigation systems at the farm and irrigation district scales using new technologies (e.g., soil moisture and canopy sensors) that better match 
irrigation with crop water requirements. These developments towards increased sustainability in agriculture also encourage good agricultural practices, such as conservation tillage, restoration of groundwater and the correct management of fertilizers [43].

As highlighted in the [44] report, the improvement of water-use efficiency and productivity depends on the introduction of better agricultural practices in synergy with new irrigation management systems. In fact, the efficiency of an irrigation system is determined more by system management than by any inherent characteristic of the system [45]. Improperly managed "hi-tech" irrigation systems can also be wasteful and unproductive, and they can cause damage to the ecosystem as well as investment losses to farmers.

\section{Case Studies}

Many Southern European countries have vast experience in the use of scarce and degraded natural resources, such as water and land. The rural mosaic of these areas is based on a combination of traditional irrigation systems and areas with extensive agrarian dynamism characterized by modern irrigation projects that have been promoted in accordance with criteria for water efficiency and food security [46]. Countries such as Spain, Portugal and Italy largely symbolize the dominance of water resources in any economic activity in these territories [47]. In such contexts, hydraulic constructions have played a central role in the attempt to control water in the agrarian plains, leading to the development of remarkable irrigation systems [48]. Consequently, the construction of irrigation canals has played a fundamental role in the management of natural and productive resources, land reclamation and ecosystem conservation [49].

In the following sections, we briefly discuss the characteristics and peculiarities of four rural irrigation consortia in Mediterranean Europe (Figure 1), with the aim of analyzing the prospects and difficulties of improving gravity-fed surface irrigation systems in these contexts.

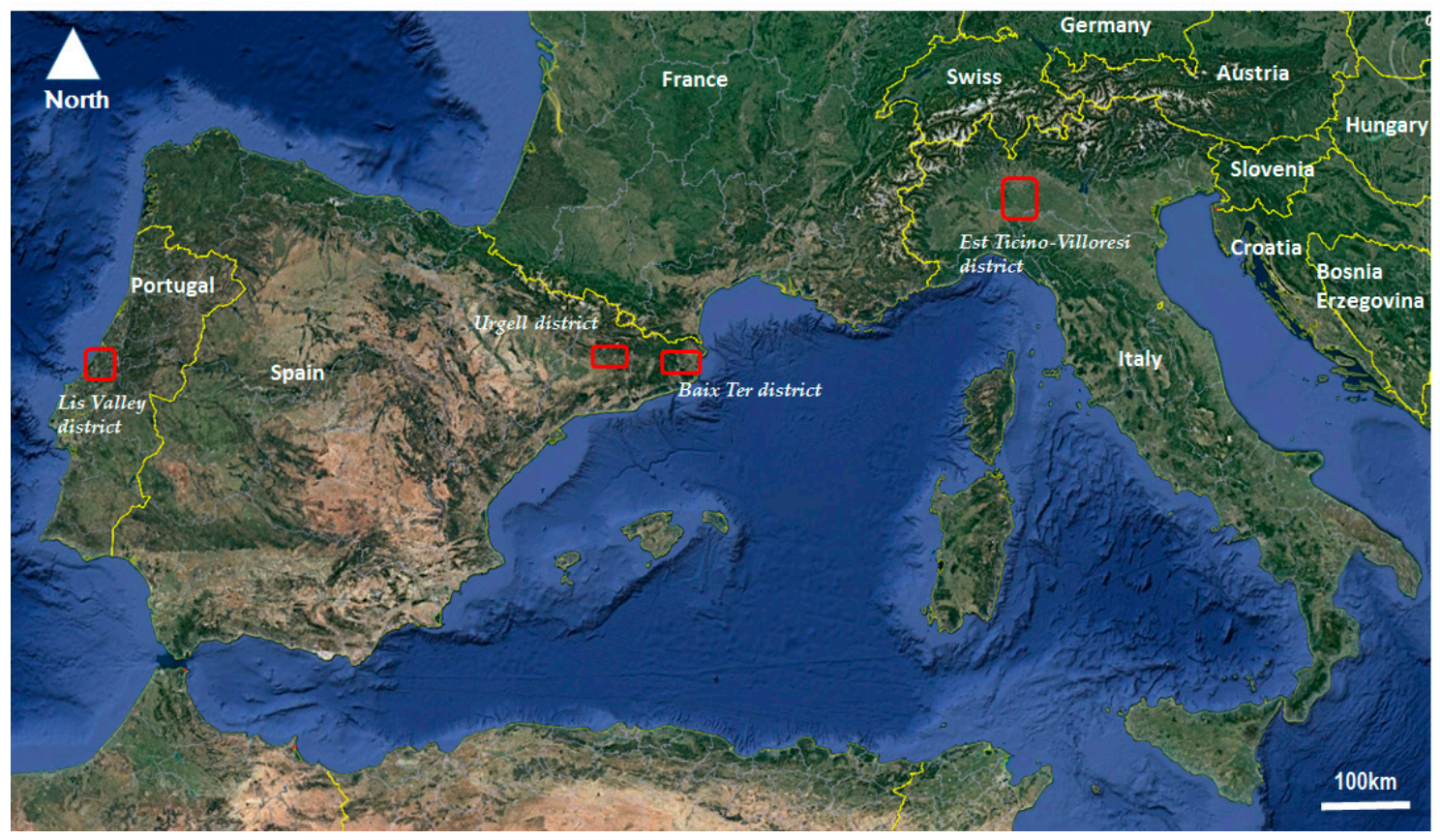

Figure 1. The location of the four irrigation districts.

\subsection{The Est Ticino-Villoresi District}

The Est Ticino-Villoresi district is located in the heart of the Padana plain and is the second largest irrigation district in Italy, supplying irrigation water to approximately 115,000 ha. The entire study area is characterized by a high number of small land-holdings with intensive, livestock-oriented practices. 
The main crops are maize and rice (in descending order). Maize is generally intended as food for livestock, while rice is generally sold at market. The pedo-climatic conditions are favorable for extensive cropping, but farming is strongly dependent on irrigation due to the high water requirements of these crops. By studying twelve years of meteorological data (from 1993 to 2013) from 10 agro-meteorological stations located in the district, Cesari de Maria et al. [2] found that during the agricultural season (April to September), the average temperature was approximately $20.2{ }^{\circ} \mathrm{C}$, while the total rainfall was approximately $360 \mathrm{~mm}$, with marked variability from year to year. The relative humidity was always high (>80\%) and implies the presence of foggy months during the winter and hot and muggy months in the summer. During the irrigation period (June to September), the average daily reference evapotranspiration values (calculated based on the FAO Penman-Monteith equation by [50]) for the months of June, July, August and September were 4.7, 4.6, 4.0 and $2.8 \mathrm{~mm} \cdot$ day $^{-1}$, respectively. The traditional irrigation techniques for the two crops consist of furrow irrigation for maize and flood irrigation for rice, with water depths from 5 to $20 \mathrm{~cm}$ from just prior to seeding (generally occurring in May) to approximately 3 weeks before harvesting (generally occurring in September).

Approximately $400 \mathrm{~m}^{3} \cdot \mathrm{s}^{-1}$ water is conveyed by gravity to all district areas by five main artificial canals that divert water from the Ticino and Adda rivers (the main two tributaries of the Po river). The Naviglio Grande, located in the western part of the district, is the oldest canal, dating back to the XIII century. It conveys a flow of approximately $64 \mathrm{~m}^{3} \cdot \mathrm{s}^{-1}$ from the Sommo Lombardo (a city close to the outlet of Lake Maggiore) to Milan, where its residual flow gives rise to the Naviglio Bereguardo (with an average flow of $5 \mathrm{~m}^{3} \cdot \mathrm{s}^{-1}$ ) and the Naviglio Pavese (with an average flow of $10 \mathrm{~m}^{3} \cdot \mathrm{s}^{-1}$ ). The latter was finished at the beginning of the XIX century to provide a navigable link from Milan to Pavia and then from the Po river to the Ticino river. It is also the main canal for supplying irrigation to the fertile lands south of Milan. The Naviglio Martesana, located in the eastern part of the Est-Ticino Villoresi district, was completed at the end of the XV century. In this district, it is the only canal originating from the Adda river, from which it diverts an average rate of $25 \mathrm{~m}^{3} \cdot \mathrm{s}^{-1}$. Finally, the Villoresi Canal is the most recent. It was built at the end of the XIX century to supply irrigation water to the lands of the North part of Milan, diverting an average of $50 \mathrm{~m}^{3} \cdot \mathrm{s}^{-1}$ from the Ticino river (Figure 2).

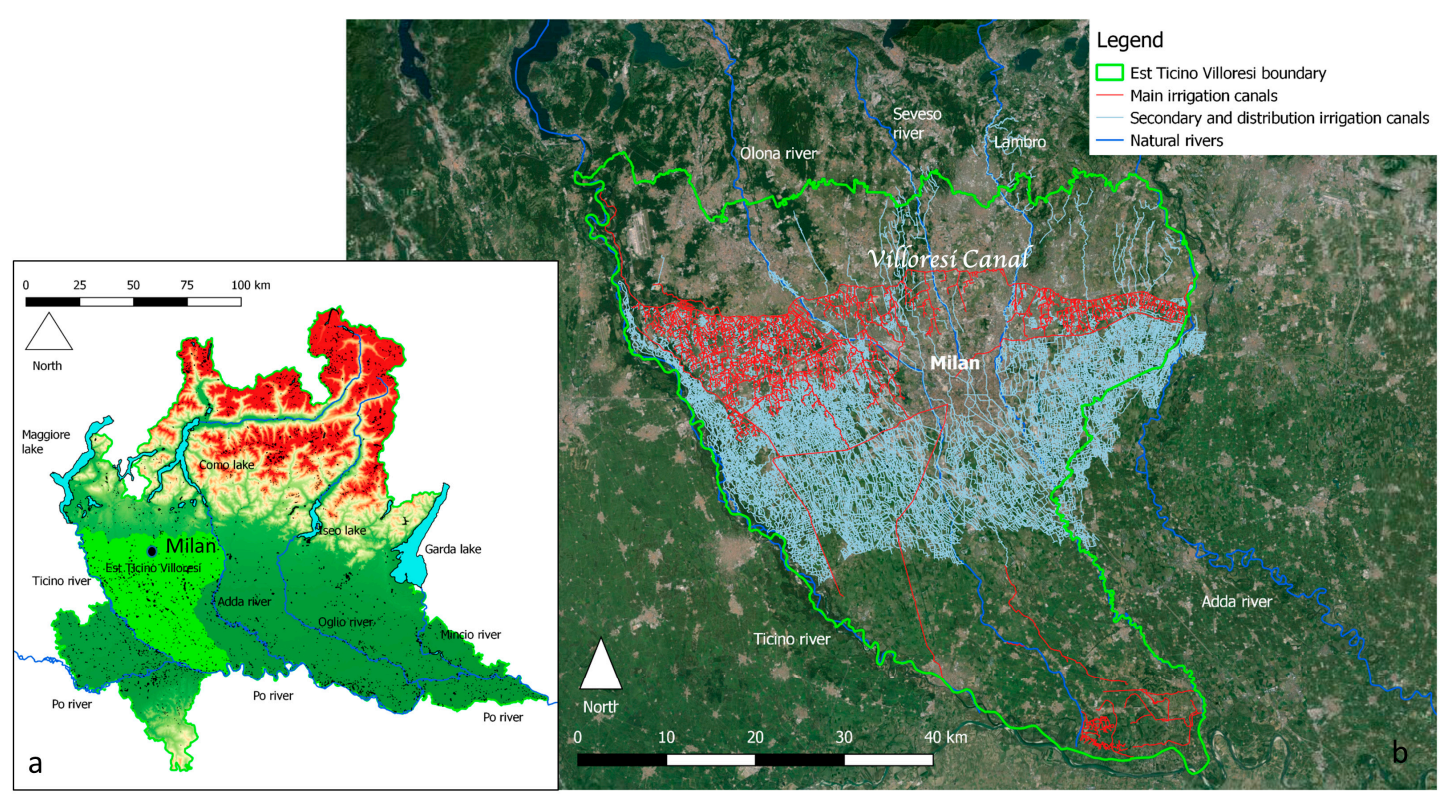

Figure 2. Location of the Est Ticino-Villoresi district inside the Lombardy Region (a); and the GIS representation of a part of the dense gravity-fed surface irrigation network, which originates from the Villoresi Canal (b). 
From these main five canals, the water is conveyed to the individual fields through a dense network of unlined open canals that have a combined total length of more than $5000 \mathrm{~km}$. The management of the main canals and of most of the irrigation network is entrusted to the Est Ticino Villoresi Consortium, which was established at the end of the XX century and represents the last heir of a long chain of historical Consortia. Along the canals (from main canals to tertiary ditches), the flow regulation is entrusted by Consortium workers who manually open and close weirs and gates to supply the correct amount of water to all areas of the irrigation district. The water supplied to the farms typically has a weekly rotation. The water delivery efficiency of the irrigation network (from the diversion point to the farm) is quite low, with an amount of seepage along the canals ranging from $5 \%$ to $40 \%$. However, these seepages are essential for groundwater recharge and for maintaining the natural equilibrium of the hydrological cycle.

From a hydrological perspective, the district is characterized by a strong interaction between groundwater and surface water. The water table of the unconfined aquifer ranges from a few meters to 30-50 $\mathrm{m}$ from the ground level, with a strong variability from zone to zone. In the district, more than 200 springs are in operation and supply water for irrigation to most of the rural areas. In many cases, groundwater directly supplies water for the irrigation of downstream fields and preserves the Minimum Flow Level in the rivers.

The irrigation network is strongly integrated into the urban fabric of the Milan metropolis, thus playing a scenic role in addition to its hydraulic function. It also represents an important historical heritage and is widely used for recreational purposes. For example, the Canale Villoresi represents a blue-green corridor between the Ticino and Adda rivers and has been enhanced through a series of projects aimed to increase cycle-tourism and light-draft boat navigability.

The lack of flow measures in the network canals makes it difficult to assess water balances on different spatial scales and control water use efficiency. Only the main canals and some secondary ditches are monitored daily by Consortium workers, who read the water level gauge inside the hydraulic structures. Modern flow meter devices have been installed only at a few points, and in these points the measure of the flow is continuous.

\subsection{The Baix Ter Irrigation District}

The Baix Ter irrigation district is located in the north-eastern region of Catalonia (Spain) and is part of the internal basins of Catalonia region (Figure 3). The water administration (planning, management and control) of this area falls under the exclusive jurisdiction of the Autonomous Community of Catalonia through the Catalan Water Agency.

The Baix Ter is an alluvial plain that represents the main agricultural area of the internal basins of the Catalonia region. The total water demand for different uses in this area is approximately $100 \mathrm{hm}^{3}$ per year, of which $70 \%$ is used to meet the water requirements of major crops, mainly summer cereals (maize and rice), fresh fruit (apple trees), fodder (lucerne and ryegrass), poplars and nurseries of ornamental ligneous plants (Figure 3). The irrigation water comes mainly from surface water catchments through dams constructed along the river and to a lesser extent from wells (approximately 800), which use water from the low Ter aquifer.

Several circumstances related to the management of water resources in the Baix Ter area must be considered. The first is competition for water use. The area has a Mediterranean climate, characterized by important variations in water availability. The water is needed not only for agriculture; a huge amount is also transferred from the Ter River towards the Barcelona metropolitan area $\left(8 \mathrm{~m}^{3} \cdot \mathrm{s}^{-1}\right)$ for urban and industrial uses, which currently use $70 \%$ of the flow rate of the Ter River and take priority when there are water restrictions. The recreational uses of this water are also very important since the Baix Ter area is included in the Costa Brava, which is important for tourism and is therefore of significant economic interest (approximately one third of the economic value generated by tourism for all of Catalonia). This is especially true during the summer period, when the agricultural water demand is the highest. A second consideration is that this area is located over the Baix Ter aquifer, with an extension of 
$165 \mathrm{~km}^{2}$ and is at risk of contravening the limits set by the EU Water Framework Directive due to its high concentrations of chlorides, nitrates and sulfates at specific locations. There are also reductions in the groundwater levels in different locations and a risk of seawater intrusion into the coastal areas. A third consideration is the high environmental and landscape importance both for the tourism interest in the area as well as from inclusion in the Montgrí, Illes Medes and Baix Ter Natural Park, which is considered an area of special environmental protection by the Autonomous Government of Catalonia. The multifunctional role of the irrigation canals of the Baix Ter district has been highlighted by $[51,52]$.

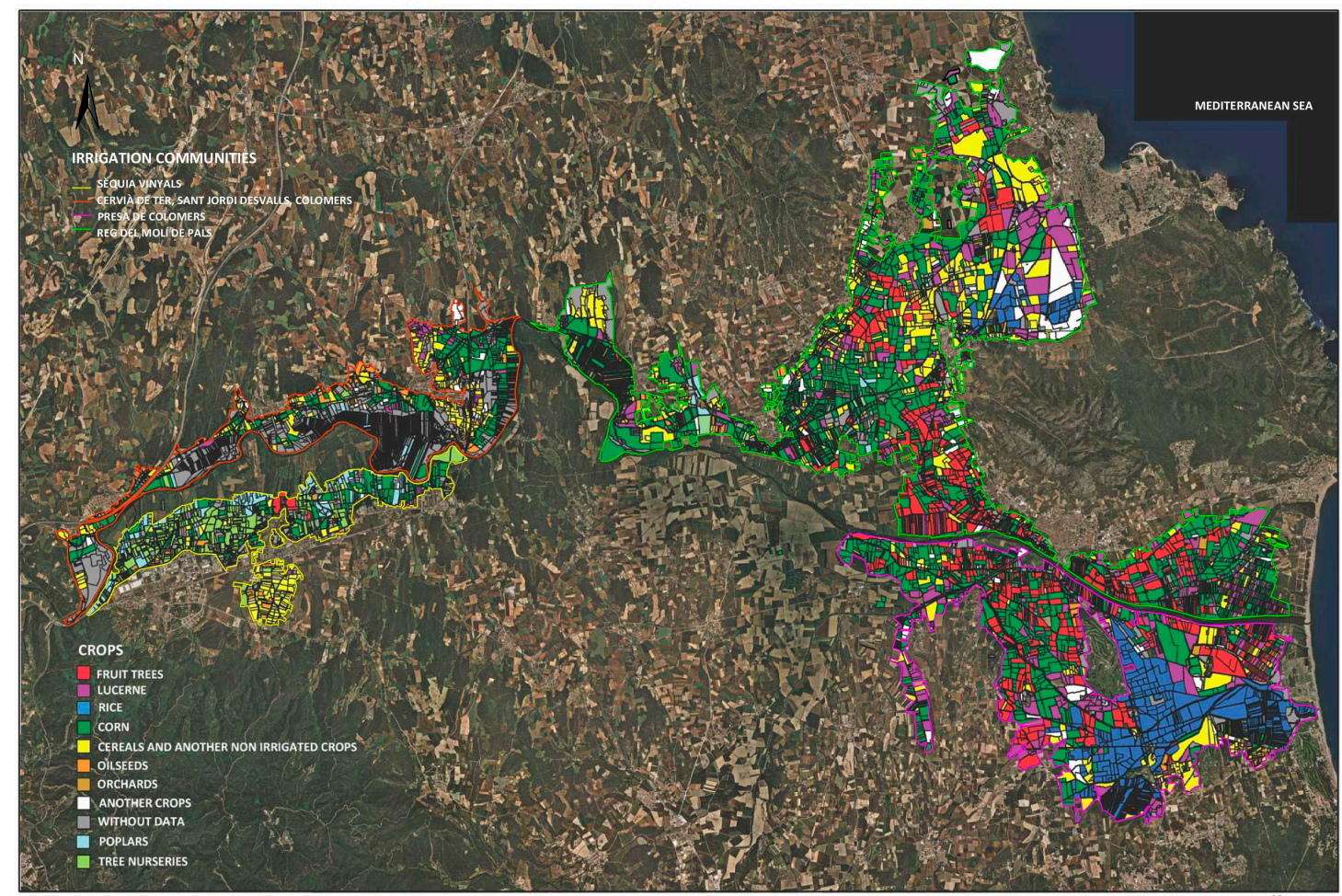

Figure 3. Location of the Baix Ter irrigation district and the Irrigation Communities (Catalonia, Spain). Crop distribution is also shown.

The irrigators of the Baix Ter area are organized into four Irrigation Communities (Sèquia Vinyals; Sèquia Cervià de Ter, Sant Jordi Desvalls i Colomers; Presa de Colomers Marge Esquerre del Riu Ter; Reg del Molí de Pals) and grouped into the Catalan Association of Irrigation Communities. The Irrigation Communities are public law corporations attached to the basin organizations. The irrigation district of the Baix Ter occupies approximately 10,000 ha and consists of approximately 2800 tax irrigators, of which approximately one quarter are professional farmers. The water uptake from the Ter River is conveyed to a system of canals and gravity ducts, which distribute water to the plots. The total length of the primary canals is approximately $120 \mathrm{~km}$. In some communities, the water concession ranges from 0.8 to $5 \mathrm{~m}^{3} \cdot \mathrm{s}^{-1}$ throughout the year, while in other communities it varies depending on the month. The channels date from several centuries ago and were originally earthen constructions with irregular sections or with dry stone masonry. In recent years, the Department of Agriculture of the Catalonian Government has planned and executed important improvement works in the irrigation network, which are basically the concrete lining of the channels or the piping canals. These are only partial actions aiming to reduce water loss along the distribution network. The investments have been partially subsidized due to their high costs.

The irrigation system in the Baix Ter district is mostly located along the surface, despite governmental economic policies promoting the transformation to pressurized irrigation, especially drip irrigation (DOGC, Num. 6947, 1 September 2015, Ordre ARP (270/2015)). The behavior 
of the farmers and Irrigation Communities can be primarily explained because surface irrigation is supposed to be a low cost to the farmer in terms of installation, with zero energy requirements. In the future, the coexistence of surface and pressurized irrigation systems in this area is predicted.

The type of water tariff paid by the farmers is for the irrigable surface area and is slightly variable according to the irrigation district, ranging from 120 to $160 € \cdot \mathrm{ha}^{-1} \cdot \mathrm{year}^{-1}$ (excluding the fee for improvement works). Assuming an irrigation amount of $7000 \mathrm{~m}^{3} \cdot \mathrm{ha}^{-1}$, the price is equivalent to $0.017-0.023 € \cdot \mathrm{m}^{-3}$. In the irrigation districts with earthen canals, $60 \%$ of the fee goes towards clearing vegetation from the channels and cleaning the beds. Usually, the water is distributed on demand, although in shortage periods it is distributed on rotation. All the moving elements of the channels are governed manually.

In the context of the geographical area (with a high competency for the inter-sectoral water use, and some periods of insufficient supply), the main concern of the irrigators is to have a guaranteed water supply. The request of the irrigators and broad social sectors at the Water Administration has resulted in a greater flow rate of the Ter River, reducing the water transfer to Barcelona metropolitan area. The implantation of markets for irrigation water in this irrigation area would guarantee the optimal reassignment of the resource during low-water periods to prevent conflicts; however, the irrigators would not accept this new tool and its associated transaction costs [53].

The Irrigation Communities are facing several problems. (i) There is a lack of knowledge regarding the irrigation water needs and discharge rates required by different crops due to the lack of technology and appropriate metering systems. This fact does not encourage irrigators to make the best use of their allocated water; (ii) The hydraulic infrastructure is based on existing manual controls and is managed only by pre-established schedules that do not allow for adjustment of the water plot deliveries to the changing irrigation requirements. Therefore, it would be necessary to have real-time and continuous control of the water levels in the canals in order to obtain optimal deliveries improving, thus, distribution and application efficiencies up to the field scale; (iii) It is challenging to operate a hydraulic control system based on a manual system that also produces losses of water and overflows within the hydraulic network; (iv) It is difficult to manage the irrigation plots. The lack of technical criteria to define input flow rates and cutting times on the plot scale affects not only the achieved efficiency in the field but also the optimal alterations to the main and secondary channels. An example of the potential that can be achieved under surface irrigation can be illustrated by the irrigation distribution uniformity of the low quarter and efficiency application achieving of 88 and 93\%, respectively, as reported by Arbat et al. [54] in a commercial furrow irrigated ornamental orchard in the Sèquia Vinyals; (v) The price the irrigators pay for the water is not consistent with the pricing policy set forth in the EU Water Framework Directive. The progressive adaptation of pricing is expected to happen and will be important for consideration.

Consequently, improving the efficiency of the surface irrigation in the Baix Ter irrigation district should be approached with the dual aims of improving the irrigation channel control and improving the irrigation at the field scale. The required technology is based on the control and automation from the plot supply to the main and secondary channels, thus solving several problems that the Irrigation Communities of the Baix Ter area are currently facing, giving them the right tools and considering economic criteria to achieve a good return on their investment. The surface irrigation system is deeply rooted in the culture and customs of the irrigator of the Baix Ter region. It is the most sustainable irrigation system, given both its lack of an operational energy consumption and its effects on life-cycle assessment of materials and carbon footprint. Furthermore, this system is fully integrated into the landscape in an attractive way. These values are particularly interesting in an area such as the Baix Ter, which is a strategic area in terms of the tourism and recreation economies.

\subsection{Urgell District}

The Segre River originates in the Pyrenees mountain range and passes through the central valley of Catalonia (NE Spain), ultimately flowing into the Ebro river. The irrigation district of the Urgell 
canal is located in this depression (Figure 4). The irrigation area is served by two main canals and four secondary canals, which supply a total area of 70,000 ha. The main water use is agriculture, but this waterway also provides urban, livestock, industrial and environmental supplies. Alfalfa, cereals, and fruits are grown. Surface irrigation is mainly used (92\%), but drip and sprinkler irrigation is also used to a lesser extent.

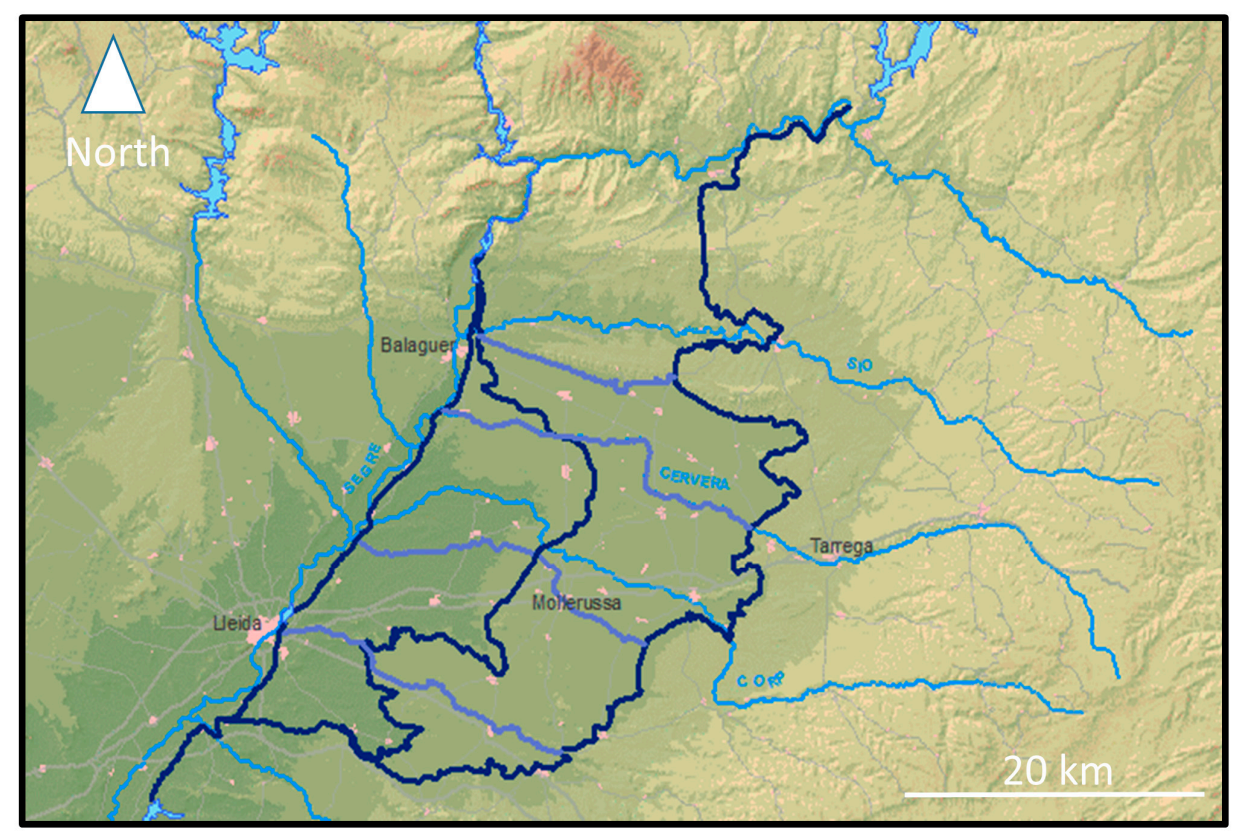

Figure 4. General view of the main and secondary canals of the Urgell Canal district.

The main canal was built in 1861, but most of the irrigation network has been modified. Most main canals $(191 \mathrm{~km})$, secondary canals $(102 \mathrm{~km})$ and tertiary canals have all been lined, although a few stretches remain unlined given their historical and scenic interest. Recent studies [55] have shown that the conveyance efficiency of the main canals considering evaporation and seepage losses is $94 \%$. When considering operation losses, this efficiency decreases to $86 \%$, indicating that operations could be improved.

The water users association is currently increasing the canal height, which would allow for a higher water capacity as well as automation. The network has several remotely controlled gates. The irrigation network is organized in rotation, with the ability to distinguish two types of zones: one in which regulating reservoirs have been built, without the need to irrigate at night, and another that represents $40 \%$ of the irrigation area, which must be irrigated at night. The latter system translates into an inconvenience for farmers and a decrease in water efficiency. A possible improvement in this area would be to automate irrigation.

Irrigation assessments have been completed [56]. These suggest that efficiency is closely related to the soil characteristics. In soils developed on thin detrital materials, irrigation efficiencies typically range between $65 \%$ and $85 \%$, while in soils developed on gravels with high infiltration rates, the efficiencies are between $20 \%$ and $40 \%$.

Before 2000, Segre river regulation was quite low to assure an adequate supply to the irrigation area, resulting in many years of shortage. For this reason, small weirs were built in drainage ditches in the lower irrigation area to derive this excess water from the highlands. This factor increases the overall efficiency.

Inside the irrigation area, there is an endorheic basin. This basin contains a swamp that has grown after the construction of the canal due to surplus irrigation water, becoming a 200 ha swamp with abundant wildlife and fishing. In 1951, they drained the swamp to allocate more land for agriculture. 
However, in 2005, it was decided to recover it to restore its ecological and landscape functions and make it a tourist resource for the area. Presently, the canal provides the same amount of water as agricultural land.

\subsection{Lis Valley District}

The Lis Valley district, from the Lis Valley Irrigation Project, is a small yet important agricultural area of the Center of Portugal, with a total area of 2000 ha managed by the Lis Water Users Association (Figure 5). Its irrigation and drainage system dates back to 1957. An annual average of approximately 7.1 million $\mathrm{m}^{3}$ of water is used to grow corn grain, rice, and horticultural crops as well as for orchards, meadows and forage.

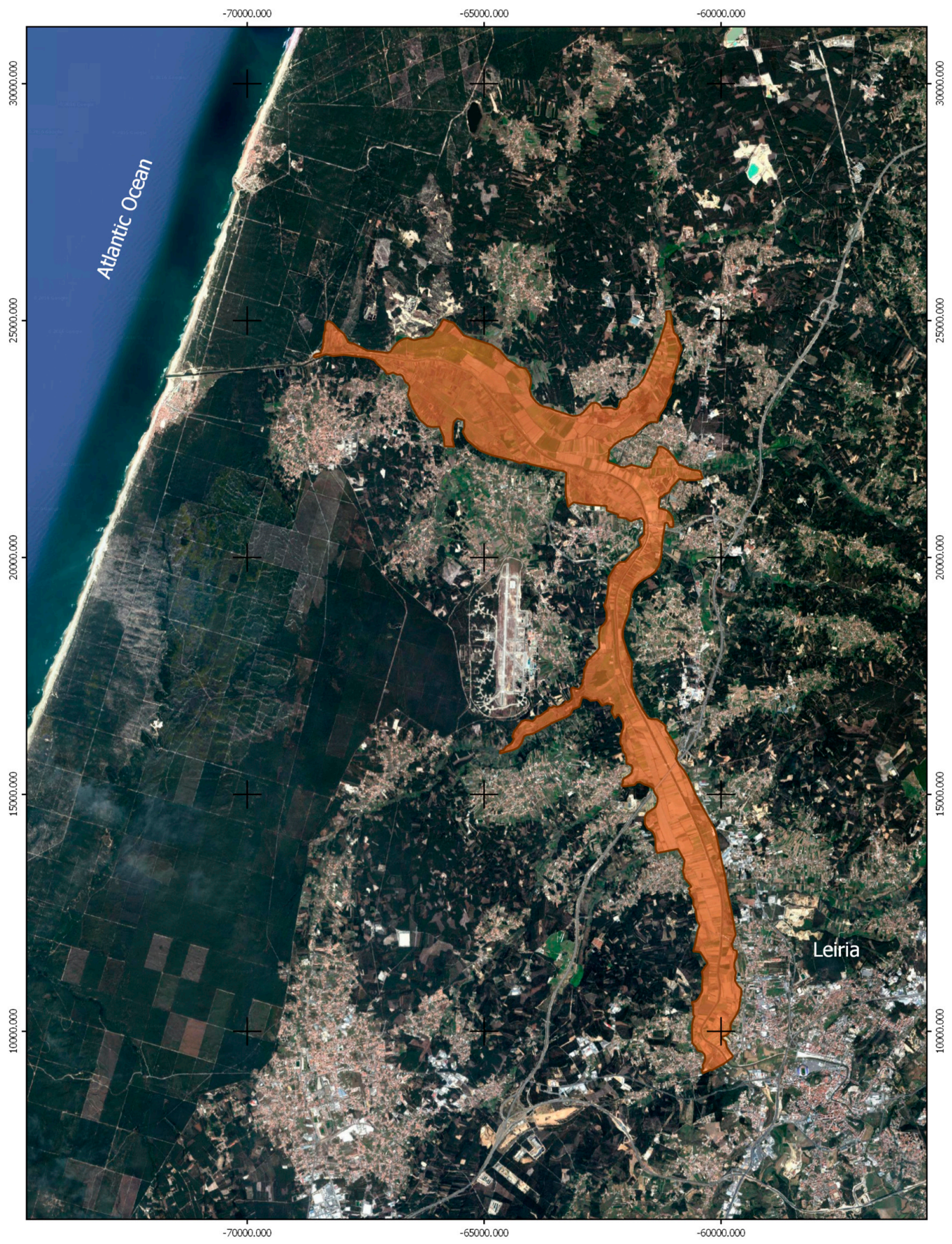

Figure 5. Location of the Lis Valley Irrigation Project (Portugal). 
The water supply to the open channels conveyance network relies on weirs installed along the Lis River and tributaries. In the dry season, it also uses water pumped from drainage ditches. The irrigation network comprises 17 weirs, two of which are modern and automatic structures. The length of the primary irrigation network is $44.5 \mathrm{~km}$; the secondary irrigation network consists of $180 \mathrm{~km}$ of small lined or earthen channels. In terms of water distribution, the most important problems are the water shortage and poor water quality in the summer (dry) period, and the absence of automation mechanisms to control water levels in the network channels, leading to malfunctions. Furthermore, there is not a monitoring system in the distribution network to support its efficient operation. At the on-farm level, there is a need to further develop the irrigation systems by improving the land levelling and the use of water distribution equipment to accurately control the inflow rates. Presently, the national government is planning for the rehabilitation of a significant part of the water distribution network that will reduce the water losses in the channels and simplify their management. It will also allow for increases in the cultivation of more profitable crops, namely, nurseries and horticultural crops. However, the study of different options for the automation of this network is of particular relevance to achieve optimized solutions of water distribution that better integrate farm irrigation.

Challenges in developing surface irrigation at the levels of off-farm (responsibility of the water users associations) and on-farm (responsibility of the individual farmers) distribution networks include improving several factors: (i) the quality of hydraulic infrastructures to reduce water losses and control flow more accurately by installing automatic control equipment in the networks; (ii) the management of collective networks through the implementation of operational plans to adjust the demand for water in each irrigation season with the corresponding distribution, which requires the integration of diverse information in real time; (iii) system design quality related to the maintenance of the land leveling at the field plot scale; (iv) irrigation control and allocation through monitoring of soil saturation and vegetation in addition to the adjustment of application times, feed rates, and required allocations; (v) water application control using automated systems to optimize application efficiency and reduce hand labour consumption; and (vi) the re-use of excess flow at the downstream end of irrigated fields.

\section{General Issues That Emerge from the Case Studies}

Analysis of the case studies has identified several water resource management issues that need to be taken into account for the improved implementation of gravity-fed surface irrigation practices and techniques in the future. (i) The high level of competition for water among agricultural, civil and industrial users, especially where rural areas are included in or strongly connected to the urban fabric is one such issue; as is (ii) the importance of environmental and recreational uses of water. For example, some agricultural areas—such as Baix Ter, which is included in the Costa Brava area-are included in regions with a high level of tourism and economic interest, especially during the summer when the water demand for agriculture is at its highest); (iii) The role of aquifer recharge due to irrigation in preventing the risks of seawater intrusion in coastal aquifers should also be considered; as well as (iv) the low efficiency in water conveyance and distribution due to the often precarious control of the infrastructure and a lack of flow regulation flexibility; (v) Irrigation scheduling decision support services that provide the farmer with information about "when" and "how much" irrigation are also lacking. In particular, specific problems that occur in study areas are (i) the lack of knowledge of crop water requirements as well as the delivered water volumes at the single farm or irrigation district scales (due in many cases to the absence of appropriate metering systems); (ii) the limitations of the existing hydraulic infrastructure based on manual controls and managed according to pre-established seasonal schedules that do not allow for shorter-term adjustments to the changing irrigation requirements; and (iii) the unmeasured seepage losses from the canal network.

\section{Reasons for These Limitations}

The lack of technically sound criteria to define the correct flow rate and cutting time of the gates strongly affects the water use efficiency at the field scale and the water delivery efficiency at 
the canal scale. Rijo and Almeida [57] showed that conveyance efficiencies for automatic systems of flow regulation, developed in the context of the Sorraia Irrigation project (Portugal), were more than $80 \%$ during the irrigation period. In contrast, Koech et al. [58] reported that the application of automatic gate irrigation systems in furrow-irrigated cotton fields in Australia has led to an application efficiency of up to $90 \%$. It follows that the problem of increasing the efficiency of gravity-fed surface irrigation systems should be approached with two synergic objectives: improving the control of flow in the irrigation canals (district scale) and improving the water application at the field scale (farm scale). Although researchers have developed new devices and practical scheduling procedures to improve gravity-fed surface irrigation systems over the last decade $[59,60]$, the adoption of these devices and procedures has been limited for many reasons.

At the farm scale, the issue most frequently mentioned by growers is the lack of financial benefits for changing their current practices, which they consider to be adequate. In many cases, the initial investment to modernize the traditional pattern of gravity-fed surface irrigation systems with automatic and remote-controlled devices is about the same investment necessary to adopt a pressurized system for irrigation. Moreover, in contexts such as Northern Italy, where extensive cultivation is mainly intended for livestock food and connected to the milk production economy, this conversion is not profitable. Therefore, future gravity-fed surface irrigation technologies should merge net farmer incomes with water efficiency and productivity so that the farmers will be persuaded to adopt these new technologies for their own economic interests while increasing irrigation efficiency. Using a financial approach to incentivize increases in water efficiency rather than an engineering one appears to be prudent when assessing irrigation performance at the farm level because any managerial (e.g., scheduling) and operational (e.g., equipment) inefficiencies associated with irrigation are implicitly included in the assessment of profits [60]. In fact, given that the current gravity-fed surface irrigation systems are mainly manually managed, such inefficiencies lead to an amplification of the time and labor costs required for irrigation, which must be subtracted from the yielded profits.

Another factor strongly limiting the modernization of the gravity-fed surface irrigation systems is the perception that farmers have about the efficient use of water for irrigation. In Knox et al. [60], the questionnaire answered by growers belonging to eight samples of farmers in eastern England showed that most of the growers surveyed (63\%) considered "irrigation efficiency" to be best defined as "applying the right amount of water at the right time in the right place". A quarter of the respondents interpreted irrigation efficiency as "maximizing the value of the water applied (Money/Volume)" and $13 \%$ as "improving production per unit of water applied (Yield weight/Volume)". The definitions relating to irrigation water use efficiency, including "improving the yield from the same amount of water" and "maximizing the proportion of water used by the plant", were not selected by any farmers. In Mediterranean contexts, this problem is exacerbated by the lack of farmer knowledge about crop water requirements and the insufficient presence of organizations (either governmental or commercial) to provide irrigation scheduling advice for farmers that adopt gravity-fed irrigation methods. Although some research on the development of irrigation decision support systems has been funded by EU in the last 10 years [61], it has not always succeeded in converting research outputs into marketable products and commercial success stories. Research activities are often more research-driven than farmer-driven, and only two projects of the 10 quoted in the work of Giannakis et al. [59] had developed a business plan to commercialize their research innovation.

Lastly, the human capital characteristics of the farm populations play a prominent role in the adoption of new irrigation management tools and technologies for gravity-fed irrigation systems. Lichtenberg et al. [62] found that farmers with a higher level of education are more likely to adopt sensor network irrigation technologies. In particular, farmers with a high school education are $23 \%$ less likely to adopt the new irrigation technology compared to those with a post-secondary degree. Genius et al. [63] recorded similar findings, i.e., farmers with a higher educational level (more than 9 years) are more likely to adopt new irrigation technology. Genius et al. [63] found also that farmers up to 60 years old are more likely to adopt new technology than farmers older than 
60 years, highlighting the short planning horizon of the older farmers. However, in the Mediterranean European countries, approximately $57 \%$ of farmers are older than 55 years old; in Portugal, Italy and Spain, these percentages are $71 \%, 61 \%$ and $55 \%$, respectively [59]. In this context, farmers exhibit substantial risk aversion and are skeptical of adopting new technologies. This uncertainty can be alleviated through on-farm testing and demonstrations, farmer-to-farmer communication and the active involvement of farmer advisory systems [61].

At the district scale, the irrigation water delivery by gravity-fed surface irrigation systems is not usually measured or is often not measured accurately, particularly at the secondary and tertiary levels. In addition, the flow rates at the intake of the delivery canals are not routinely recorded. The reasons for these failings are mainly due to the complexity that the gravity-fed surface irrigation system networks have developed over the centuries. Many canals have a mixed use and are important for both the delivery and drainage of water from the fields. In several cases, this network is convoluted and abstruse.

The lack of water measurements and poor quality of district records discourage the irrigation Consortium and Association from the implementation of new irrigation technologies that aim to improve water conveyance efficiency and resource allocation [64]. Moreover, the lack of methodologies for assessing the water delivery performance of the open irrigation canals makes the quantification of the gap between the potential and actual performance of these irrigation systems challenging [65].

\section{What Can We Do?}

\subsection{Technical Advice}

To address the problems described above, we believe that a practicable requalification of gravity-fed surface irrigation systems in the context of rural Mediterranean Europe could be achieved through strategies that evolve from trinomial Measure-Model-Management $\left(\mathrm{M}^{3}\right)$. In the following, we try to explain this concept in light of the literature results obtained in different world contexts.

Measuring facilitates the analysis of gravity-fed irrigation delivery systems in terms of adequacy, efficiency, dependability, and equity of water delivery [66]. The measures could provide a quantitative assessment not only of the overall irrigation system performance but also of the contributions to the total performance from the structural and management components of the system. For example, in the works of [67-69], the adequacy, efficiency, dependability, and equity indexes of open canals in Mali, Turkey and Egypt ranged from 0.20 to 0.90 , demonstrating the high possibility of improving the performances of the delivery systems adopting automated and remote-controlled operational procedures. Despite this, many studies on the possibility of assessing the water delivery performance of gravity-fed irrigation systems are present in the literature in the rural contexts of the United States of America, Africa and Southeast Asia [64,70], whereas no research has currently been completed by authors in Mediterranean European contexts. This is due to the lack of flow measures and the necessity of building hydraulic structures for reliably measurements. However, modern technologies that are based on optical sensors and on open-hardware devices could be suitable for the continuous and real-time control of flows in complex situations or open-unlined irrigation canals [71-73]. The work of Luthi et al. [74] on a smartphone application that calculates the flow by analyzing a few seconds of a movie sequence that is recorded by the operator on-site is a good example of such research. The flow is calculated based on measurements of the water level, the surface velocity obtained from Particle Image Velocimetry (PIV) technique and a priori knowledge on the canal geometry. In Mediterranean Europe, this application could have several advantages, such as reducing the work time of Consortium workers to take measurements and improving the ease of data collection, which could simply be sent via SMS to a dedicated database.

Models can be subdivided into three main categories. The first category focuses on the hydraulic analysis of irrigation canal flow networks, while the second aims to assess crop water requirements at farm and district scales. The third category uses decision support systems for scheduling irrigation. 
The first two typologies of the models could be considered for the reasonable operation and planning with optimized irrigation and water allocation. For example, the study by Kim et al. [75] carried out in a paddy district of South Korea showed the good performance (in terms of calibration and validation) of the combined hydraulic-hydrologic Storm Water Management Model (SWMM) for providing hydraulic analysis of the irrigation network and water balance in the fields. In Mediterranean European contexts, this model could assist in promoting accurate irrigation scheduling on the district scale based on crop water requirements as well as optimizing the distribution of water in the irrigation network through sluice gate control. In addition, conjunctive modelling based on hydrological-economic features could investigate the interdependencies between gravity-fed surface irrigation systems, the district water balance and the economic impact of new irrigation decision strategies [5]. Simulations and scenarios of the optimized irrigation scheduling and water allocations could be produced, thus improving the irrigation planning processes from the farm to the district scale [76].

We believe that for a fast feedback effect on Mediterranean European rural territories of the $\mathrm{M}^{3}$ approach, the gravity-fed surface irrigation systems should be equipped with automatic and remote-controlled gates whenever possible as well as flow meters for the continuous measurement of the irrigation flow both in the canals and into the fields.

At the farm scale, Australian experiences in the cotton fields have shown that the application of these automatic systems leads to the maximization of the application and distribution uniformity efficiencies $(>85 \%)$, ensuring that the water reaches the end of the field with a uniform level in all points of the field [58]. Currently, only two experiments are running in Spain and Italy for providing the crop water requirements using automatic and remote controlled prototypes of bay-gates. In Spain, automatic furrow irrigation is tested on maize and grass using soil humidity probes at different depths in the field as the control of crop water needs (Figure 6a), while in Italy, automatic sluices governed by water level sensors in the field maintain the correct flood state of flood in the paddy field, as shown in Figure 6b [77].

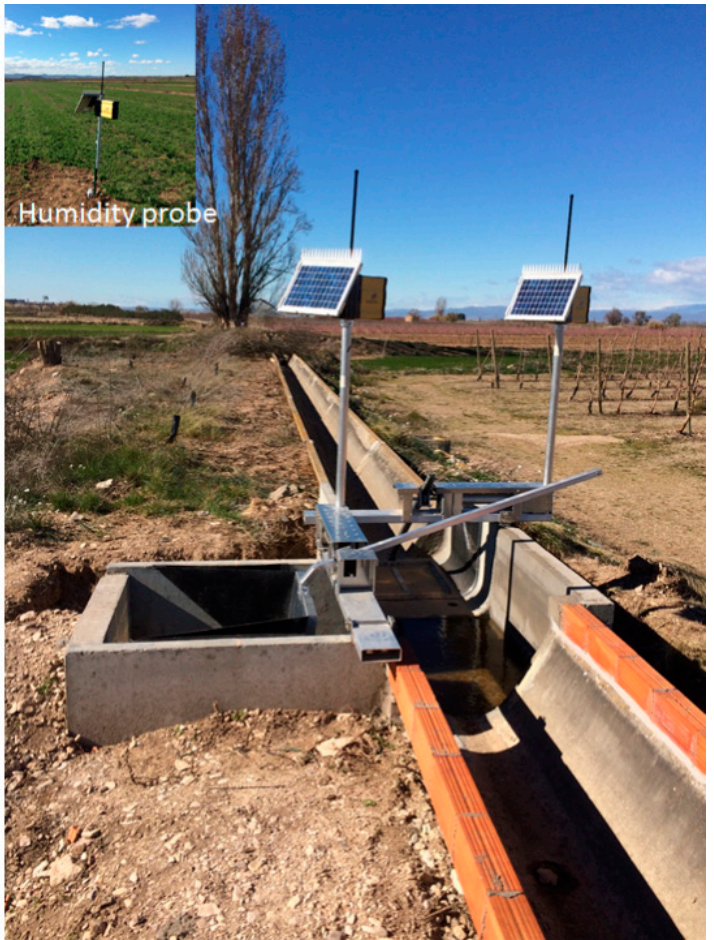

(a)

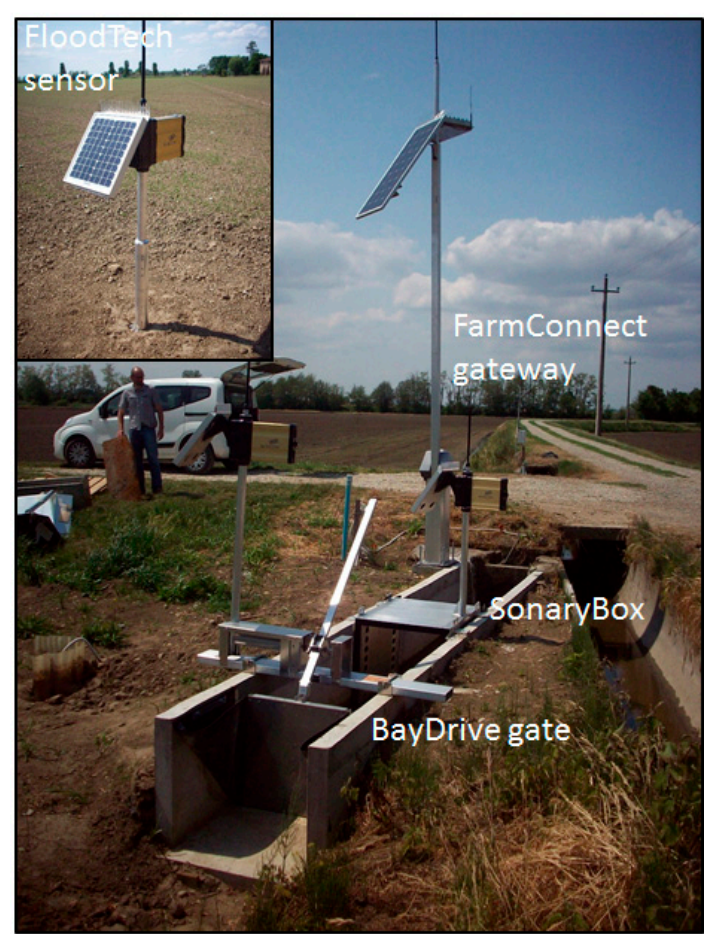

(b)

Figure 6. Prototypes of automatic and remote controlled-gates for gravity-fed surface irrigation of grass field in Northern Spain (a) and rice field in Northern Italy (b). 
At the district scale, the overview provided by Oakes et al. [78] on the collective experience gained over the last 20 years in the development and application of automation technology to the open channel irrigation sector, primarily in Australia but more recently in the USA, China, New Zealand, India, Vietnam, France and Italy, highlighted that the automation and remote control of gravity irrigation systems will be useful for improving the productivity of irrigated agriculture to reach food production goals over the next several years. However, they suggest that the key success factor for the modernization of the gravity-fed irrigation systems is a smooth transition to an automated irrigation system, implementing sound education/information/training programs for both the consortium staff and customers in the use and maintenance of these systems.

\subsection{Economic Advice}

The European Agricultural Fund for Rural Development supports investments in irrigation scheduling infrastructure to provide economic and environmental benefits. Several measures can be used for the protection and maintenance of water resources in agriculture, namely, measure 6.1.01 (for the realization and modernization of agricultural holdings), measure 7.6.01 (for infrastructure related to the development and adaptation of agriculture and forestry), measure 1.2.01 (for the vocational training and information actions), measures 10 and 16 (for agri-environment payments and cooperation), and measure 4.4.02 (for non-productive investments for irrigation management). In total, approximately 50\% of the budgets of Rural Development Programmes in EU member states has been allocated to measures that relate to a certain or limited extent to water for the 2014-2020 period.

\subsection{Reviving Interest in Gravity-Fed Surface Irrigation Systems}

Finding solutions that safeguard the gravity-fed surface irrigation systems is necessary to maintain the environmental and ecological equilibrium of rural areas in Southern Europe and to preserve the cultural heritage of these irrigation systems. The multi-functional characteristics of the gravity-fed surface irrigation systems (Figure 7) could be safeguarded by the conservation and revitalization of these systems driven by historic, ethnological, educational, ecological and environmental interests $[79,80]$. Two major directions could serve as the foundation for future revival initiatives. On the one hand, the focus could be on the preservation of gravity-fed surface irrigation systems themselves as an agro-cultural heritage [81,82]. On the other hand, the focus could be on the nature conservation benefits that result from these systems $[83,84]$.
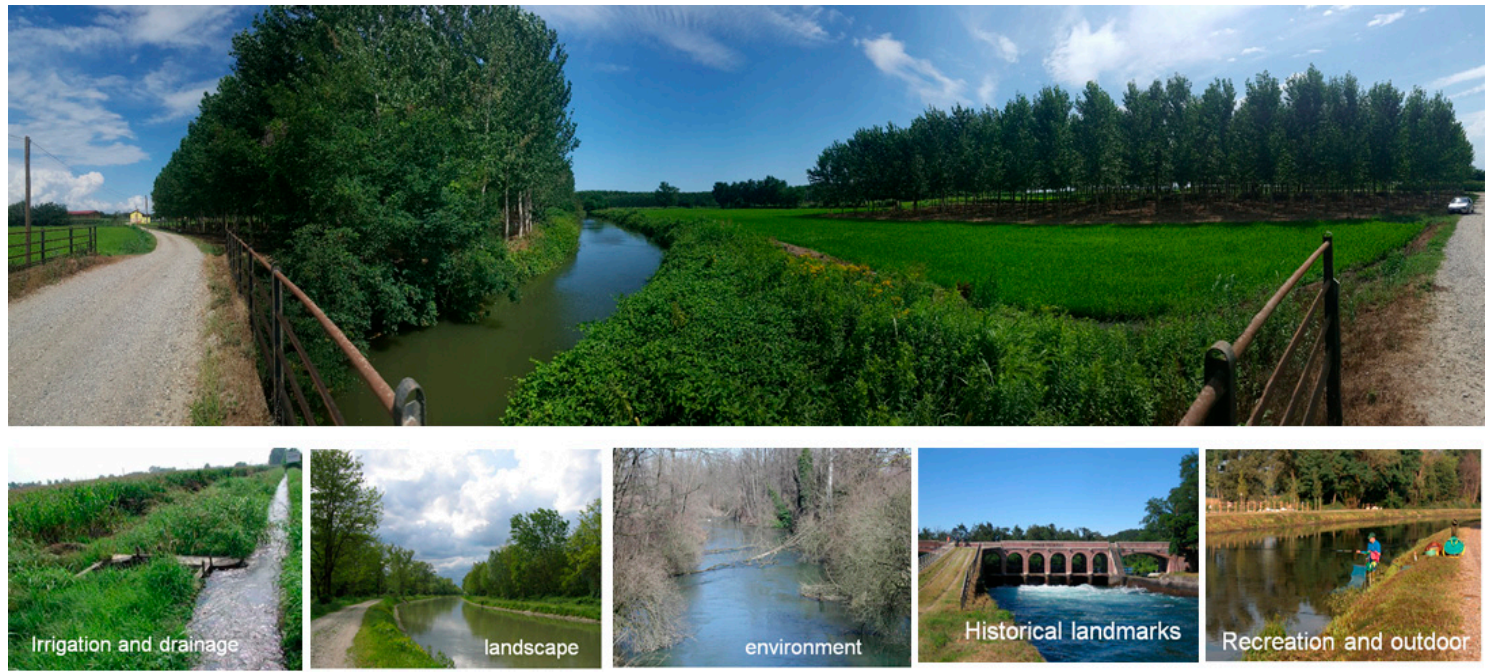

Figure 7. Example of the multi-functionality character of the gravity-fed surface irrigation system in Northern Italy rural contexts. 
In the first case, the traditional structure and networks of gravity-fed surface irrigation systems could be considered as an "eco-museum", in which their complexity and ancient origin could be investigated through historical and landscape studies and possibly explained in situ during educational visits. In fact, the risk of a potential demise of traditional gravity-fed surface irrigation systems is equivalent to the loss of traditional knowledge. Gravity-fed surface irrigation is a typical skill-oriented technology [85]. Currently, gravity-fed surface irrigation practitioners are able to combine their rich hands-on experience with the local traditional knowledge. Their skills may be implemented into the new automatic gravity-fed surface irrigation systems with specific irrigation scheduling management tools according to the crop requirements and agronomic practices.

In the second case, the nature conservation benefits of the gravity-fed surface irrigation systems have been widely demonstrated in the case study areas, where the centuries-long development of this type of irrigation system has contributed to the development of their characteristic agro-natural environment $[86,87]$. For example, the prolonged presence and circulation of water due to the surface irrigation of paddy fields from sowing to harvest represents a distinguishing feature of some of these irrigated areas (e.g., in parts of the Northern Italy plains and in the Baix Ter irrigation districts) that has been included in the European ecological network NATURA 2000 and is on the official list of the European Special Protected Areas.

In addition to heritage preservation and nature conservation, additional environmental factors have emerged as driving forces for the preservation and restoration of gravity-fed surface irrigation systems, although the integrated landscape-ecological consequences of these systems require further research $[88,89]$. As highlighted in the previous paragraphs, gravity-fed surface irrigation schemes are thought to be generally of low water use efficiency or even to be "wasteful". To establish whether an irrigation technique is efficient for a specific territory, it is necessary to quantify the water availability and the irrigation water demand for that area and then to evaluate the efficiency of the irrigation systems. However, the irrigation efficiency should be evaluated using a larger-scale approach (from the irrigation district to the basin), considering not only the hydraulic efficiency but also the secondary benefits [90]. Such secondary benefits range from recreational features, including the picturesque rural roads bordering the canals, to ecological functions, including the preservation of the traditional fauna and flora of the rural landscape. These factors improve the multi-functional character of the gravity-fed surface irrigation systems. In a case study in northern Portugal, Van den Dries and Portela [86] demonstrated how the conversion of a gravity-fed surface irrigation system into a pressurized system has paradoxically provoked a reduction in the deliveries at the farm level. In gravity-fed surface irrigation systems, the water excess on the fields was returned to the natural downstream waterway, thus representing the new (and in many cases, the majority) input for the irrigation of the downstream farms. These 'losses', which are generally due to drainage or percolations, are important for regional aquifer recharge and for maintaining the minimum flow and level in the rivers [91]. In addition, the water 'losses' along the unlined water conveyance and distribution systems represent a possibility for aquifer recharge management [92]. Interestingly, a recent study by Seraphin et al. [93] found that using isotopes for tracing the contributions to the groundwater recharge of the Cru aquifer in France, showing that about $69 \% \pm 9 \%$ of the surface recharge is caused by irrigation return flow i.e., from specific irrigation practices and the presence of unlined canals. Moreover, many assumptions suggest that the quality of water that flow in the gravity-fed surface irrigation canals is comparable with that in the feeding rivers. In the light of this consideration, the seepage of water from unlined canals, in contrast to deep percolation at the fields, preserves groundwater from the chemical contamination of agronomic treatments, pursuant to the EU directives for water pollution reductions (i.e., "nitrate directive" 91/676/CEE [94]).

Lastly, the perfect integration found between gravity-fed surface irrigation canals and urban fabric in many situations such as in Milan metropolis, confers to these irrigation systems a new important role related to a "hydraulic protection of the territory" [95]. In fact, the huge increase of impervious areas as a consequence of the urban expansion, in the last decades, has caused an unexpected increase 
in the frequency and intensity of flood events. In these urban contexts, where the areas for flood storage are hard to find, an alternative solution for flood risk mitigation (in addition to the green infrastructure projects) could be the rehabilitation of interconnections between sewer and irrigation canals with spillways designed for allowing rainwater to be stored into the irrigation network.

\section{Conclusions}

In the last decade, concerns about water scarcity have focused on the relationship between irrigation and other competing water uses. Especially in the countries of Southern Europe, where gravity-fed surface irrigation systems are the most common infrastructure type for crop and pasture irrigation, many policy guidelines have started to promote the transformation of these traditional systems into pressurized ones to avoid waste and increase the supply efficiency. However, as highlighted in this work, to face the complexity of irrigation water resource management conflicts and address the challenges in improving irrigation practices, "hard-path" approaches are not enough. In fact, case studies show that gravity-fed surface irrigation systems have important environmental and ecosystem functions in addition to their hydraulic role and are part of the cultural heritage of rural Southern Europe. Some of these benefits are connected with maintaining the riparian vegetation and habitats along the canals, recharging the groundwater supply, and providing areas for recreation activities and tourism. Thus, designing smart "soft-path" measures will be possible to increase the flexibility of the gravity-fed surface irrigation systems in response to the projected climate and changes in water availability. These designs should consider distributed and participatory irrigation managements, on-demand irrigation, low-cost and reversible infrastructural interventions, flow measures and automatic and real-time controls. A new Irrigation-Energy-Environmental-Landscape-Cultural Heritage nexus has been added to the more traditional Energy-Irrigation nexus and Food-Energy-Irrigation nexus [96], demonstrating that if the gravity-fed surface irrigation systems currently present and deeply-rooted in Mediterranean rural contexts are opportunely restored, they are preferred over "modern" systems (such as pressurized pipes) because they provide "efficiencies" in many fields beyond their hydraulic functions. In particular, in contrast to the scarce supply efficiency at the farm scale, the effective efficiency of these irrigation systems at the district or basin scale is emblematic, given their capacity to exchange water with the subsoil, reuse field runoff and feed the rivers. Hence, ecosystem functions and landscape characteristics of the rural environments are ensured, guaranteeing favorable outcomes for all agro-environmental aspects. In our opinion, a smart restoration of the gravity-fed surface irrigation system in Southern Europe areas could be obtained using the $\mathrm{M}^{3}$ approach described in Section 5.1, combining flow measures and soft infrastructural improvements with hydraulic-hydrological and decision-support models as well as matching multidisciplinary competences and water user needs. It has become increasingly clear that the analysis of irrigation system developments is necessary for managing these territories, and this requires considering the availability of natural resources to interpret the changing demands of users and address the existing and potential conflicts that will arise between consumptive and non-consumptive water uses. In conclusion, we wish that with this work, the awareness of the importance and uniqueness of some Southern Europe gravity-fed surface irrigation systems will increase. It is our hope that in the future, agricultural and environmental policies will be further safeguarded, encouraging additional research on their continued enhancement and rehabilitation.

Acknowledgments: This work arises from the need to protect and preserve the typical gravity-fed surface irrigation systems belonging to the Mediterranean areas of Europe. The authors are working for rehabilitating these irrigation systems with a new sustainable appeal aimed to increase the water management performance at field and district scales. They are actively cooperating with local authorities for the implementation of measures necessary for the protection and requalification of these irrigation systems. A special thanks to the journal editor and anonymous reviewers for their valuable suggestions and comments. 
Author Contributions: Daniele Masseroni, Claudio Gandolfi, Arianna Facchi and Guido Sali conceived and designed the structure of the manuscript as well as the description of the Italian case study, European policies and discussion paragraph. Francisco Ramirez de Cartegna, Joaquim Monserrat and Sandra Ricart analyzed the problems into the two Spain case studies while José Manuel Gonçalves and Isabel de Lima analyzed the Portuguese one.

Conflicts of Interest: The authors declare no conflict of interest.

\section{References}

1. EUROSTAT. 2016. Available online: http://epp.eurostat.ec.europa.eu/portal/page/portal/statistics/ search_database (accessed on 29 December 2016).

2. Cesari de Maria, S.; Rienzner, M.; Facchi, A.; Chiaradia, E.A.; Romani, M.; Gandolfi, C. Water balance implications of switching from continuous submergence to flush irrigation in a rice-growing district. Agric. Water Manag. 2016, 171, 108-119. [CrossRef]

3. Latruffe, L.; Piet, L. Does Land Fragmentation Affect Farm Performance? A Case Study from Brittany; Factor Markets Working Paper No. 40; INRA: Paris, France, 2013.

4. BioGesteca Quaderno Gestione della Risorsa Irrigua Biogesteca Project founded by Regione Lombardia. Regione Lombardia. 2014. Available online: http:/ /www.enterisi.it/upload/enterisi/documentiallegati/ PROVOLOBiogesteca\%20Mortara\%20gennaio\%202014p13660248.pdf (accessed on 28 January 2014).

5. Gandolfi, C.; Sali, G.; Facchi, A.; Tediosi, A.; Bulgheroni, C.; Rienzner, M.; Weber, E. Integrated modelling for agricultural policies and water resources planning coordination. Biosyst. Eng. 2014, 128, 100-112. [CrossRef]

6. Ricart, S.; Ribas, A.; Pavón, D. Modeling the stakeholder profile in territorial management: The Segarra-Garrigues irrigation system, Spain. Prof. Geogr. 2016, 68, 496-510. [CrossRef]

7. Ricart, S.; Ribas, A.; Pavón, D. Qualifying irrigation system sustainability be means of stakeholder perceptions and concerns: Lessons from the Segarra-Garrigues Canal, Spain. Nat. Resour. Forum. 2016, 40, 77-90. [CrossRef]

8. Zaccaria, D.; Passarella, G.; D'Agostino, D.; Giordano, R.; Sandoval, S. Risk assessment of aquifer salinization in a large-scale coastal irrigation scheme, Italy. CLEAN Soil Air Water 2016, 44, 371-382. [CrossRef]

9. Sun, Y.; Jansen-Verbeke, M.; Min, D.; Cheng, S. Tourism potential of agricultural heritage systems. Tour. Geogr. 2011, 13, 112-128. [CrossRef]

10. Ricart, S.; Clarimont, S. Modelling the links between irrigation, ecosystem services and rural development in pursuit of social legitimacy: Results from a territorial analysis of the Neste System, Hautes-Pyrénées, France. J. Rural Stud. 2016, 43, 1-12. [CrossRef]

11. Plusquellec, H. Modernization of large-scale irrigation systems: Is it an achievable objective or a lost cause. Irrig. Drain. 2009, 58, S104-S120. [CrossRef]

12. Brummel, R.F.; Nelson, K.C. Does multifunctionality matter to US farmers? Farmer motivations and conceptions of multifunctionality in dairy systems. J. Environ. Manag. 2014, 146, 451-462. [CrossRef] [PubMed]

13. Huang, J.; Tichit, M.; Poulot, M.; Darly, S.; Li, S.; Petit, C.; Aubry, C. Comparative review of multifunctionality and ecosystem services in sustainable agriculture. J. Environ. Manag. 2015, 149, 138-147. [CrossRef] [PubMed]

14. McGuire, M.; Morton, L.W.; Arbuckle, J.G.; Cast, A.D. Farmer identities and responses to the social-biophysical environment. J. Rural Stud. 2015, 39, 145-155. [CrossRef]

15. Lemaire, G.; Franzluebbers, A.; Carvalho, P.C.; Dedieu, B. Integrated crop-livestock systems: Strategies to archive synergy between agricultural production and environmental quality. Agric. Ecosyst. Environ. 2014, 190, 4-8. [CrossRef]

16. WATPAD. WATPAD—WATer Impacts of PADdy Environment Project; Funded by Fondazione Cariplo: Milano, France, 2015.

17. Haie, N.; Keller, A.A. Effective efficiency as a tool for sustainable water resources management. J. Am. Water Resour. Assoc. 2008, 44, 961-968. [CrossRef]

18. Mateos, L. Identifying a new paradigm for assessing irrigation system performance. Irrig. Sci. 2008, 27, 25-34. [CrossRef]

19. Masseroni, D.; Facchi, A.; Gandolfi, C. Is Soil Water Potential a Reliable Variable for Irrigation Scheduling in the Case of Peach Orchards? Soil Sci. 2016, 181, 232-240. [CrossRef] 
20. Rault, P.; Jeffrey, P. On the appropriateness of public participation in integrated water resources management: Some grounded insights from the Levant. Integr. Assess. 2008, 8, 69-106.

21. Martins, G.; Brito, A.G.; Nogueira, R.; Ureña, M.; Fernández, D.; Luque, F.J.; Alcácer, C. Water resources management in southern Europe: Clues for a research and innovation based regional hypercluster. J. Environ. Manag. 2013, 119, 76-84. [CrossRef] [PubMed]

22. Singh, A. Soil salinization and waterlogging: A threat to environment and agricultural sustainability. Ecol. Econ. 2015, 57, 128-130. [CrossRef]

23. Merot, A.; Wery, J.; Isbérie, C.; Charron, F. Response of a plurispecific permanent grassland to border irrigation regulated by tensiometers. Eur. J. Agron. 2008, 28, 8-18. [CrossRef]

24. Food and Agriculture Organization of the United Nations (FAO). The State of the World's Land and Water Resources for Food and Agriculture (SOLAW)—Managing Systems at Risk; Food and Agriculture Organization of the United Nations and London: Rome, Italy, 2011.

25. Food and Agriculture Organization of the United Nations (FAO). Climate Change, Water and Food Security; FAO Water Reports No. 36; Food and Agriculture Organization of the United Nations: Rome, Italy, 2011.

26. Bizikova, L.; Roy, D.; Swanson, D.; Venema, H.D.; McCandless, M. The Water-Energy-Food Security Nexus: Towards a Practical Planning and Decision-Support Framework for Landscape Investment and Risk Management; International Institute for Sustainable Development: Winnipeg, MB, Canada, 2013.

27. Andrews-Speed, P.; Bleischwitz, R.; Boersma, T.; Johnson, C.; Kemp, G.; VanDeveer, S.D. The Global Resource Nexus: The Struggles for Land, Energy, Food, Water, and Minerals; Transatlantic Academy: Washington, DC, USA, 2012.

28. Turral, H.; Svendsen, M.; Faures, J.M. Investing in irrigation: Reviewing the past and looking to the future. Agric. Water Manag. 2010, 97, 551-560. [CrossRef]

29. European Commission. Directive 2000/60/EC of the European Parliament and of the Council establishing a framework for the Community action in the field of water policy. Off. J. Eur. Communities 2000, 327, 1-72.

30. Ministerio de Agricultura, Alimentacion y Medio Ambiente (MAGRAMA). Encuesta sobre Superficies y Rendimientos de Cultivos. Informe sobre Regadios en España; MAGRAMA: Madrid, Spain, 2015. (In Spanish)

31. Corominas, J. Water and energy in irrigation, in the era of sustainability. Ing. Agua 2010, 17, $219-233$. (In Spanish)

32. Alarcon, J.; Garrido, A.; Juana, L. Modernization of irrigation systems in Spain: Review and analysis of decision making. Int. J. Water Resour. D 2016, 32, 442-458. [CrossRef]

33. Allan, C. Rethinking the 'Project': Bridging the polarized discourses in IWRM. J. Environ. Pol. Plan. 2012, 14, 231-241. [CrossRef]

34. Jacobs, M.H.; Buijs, A.E. Understanding stakeholders' attitudes toward water management interventions: Role of place meanings. Water Resour. Res. 2011, 47. [CrossRef]

35. DM 15/09/2015 $n^{\circ} 213$. Approvazione Delle Linee Guida per la Regolamentazione da Parte Delle Regioni Delle Modalita' di Quantificazione dei Volumi Idrici ad uso Irriguo. 2015. Available online: http:/ /www.regioni.it/news/2015/09/15/d-m-31-07-2015-linee-guida-regolamentazione-modalitaquantificazione-volumi-idrici-uso-irriguo-420693/ (accessed on 30 December 2016). (In Italian)

36. Levidow, L.; Zaccaria, D.; Maia, R.; Vivas, E.; Todorovic, M.; Scardigno, A. Improving water-efficient irrigation: Prospects and difficulties of innovative practices. Agric. Water Manag. 2014, 146, 84-94. [CrossRef]

37. Evans, R.G.; Sadler, E.J. Methods and technologies to improve efficiency of water use. Water Resour Res. 2008, 44. [CrossRef]

38. Commission of the European Communities (CEC). Follow Up Communication on Water Scarcity and Droughts in the European Union COM 2007, 414 Final, [SEC(2008) 3069]; CEC: Brussels, Belgium, 2008.

39. European Parliament. Addressing the Challenge of Water Scarcity and Droughts in the European Union; European Parliament Resolution of 9 October 2008 on Addressing the Challenge of Water Scarcity and Droughts in the European Union (2008/2074 (INI)); European Environment Agency: Copenhagen, Denmark, 2008.

40. Eco-Innovation Observatory (EIO). Water Innovation: How Eco-Innovation Can Contribute to the Sustainability of Europe's Water Resources. EIO Thematic Report. 2011. Available online: http://www.ecoinnovation.eu/media/EIO_Thematic_Report_Water_May_2011.pdf (accessed on 30 December 2016).

41. Ringler, C.; Bhaduri, A.; Lawford, R. The nexus across water, energy, land, and food (WELF): Potential for improved resource use efficiency? Curr. Opin. Environ. Sustain. 2013, 5, 617-624. [CrossRef] 
42. WssTP. Irrigated Agriculture Water Saving Options in IrrigationL Looking for Efficient Techniques, Irrigation Management and Adapted Cropping Practices. Water Supply and Sanitation Technology Platform (WssTP). 2012. Available online: http://www.wsstp.eu/files/WSSTPX0001/library/agriculture/SP\% 20Agriculture\%20VI.pdf (accessed on 28 December 2016).

43. COPA (Committee of Professional Agricultural Organisations); General Confederation of Agricultural Cooperatives (COGECA). COPA-COGECA Position on Water Scarcity and Drought; COPA-COCEGA: Brussels, Belgium, 2007. Available online: http:/ / www.copa-cogeca.be/Menu.aspx (accessed on 28 May 2007).

44. COPA (Committee of Professional Agricultural Organisations); General Confederation of Agricultural Cooperatives (COGECA). Water and Agriculture under a Changing Climate; COPA-COGECA: Brussels, Belgium, 2013.

45. Smith, R.J.; Uddin, J.M.; Gillies, M.H.; Moller, P.; Clurey, K. Evaluating the performance of automated bay irrigation. Irrig. Sci. 2016, 34, 175-185. [CrossRef]

46. Ricart, S. Improving the management of water-multifunctionality through stakeholder involvement in decision-making processes. Util. Pol. 2016, 43, 71-81. [CrossRef]

47. Malorgio, G. L'agriculture, l'agroalimentaire, la pêche et le développement rural en Italie. Opt. Mediterr. 2008, 61, 265-293. (In French)

48. Ertsen, M.W. Colonial irrigation: Myths of emptiness. Landsc. Res. 2006, 31, 146-167. [CrossRef]

49. Kaika, M. Dams as symbols of modernization: The urbanization of nature between geographical imagination and materiality. Ann. Assoc. Am. Geogr. 2006, 96, 276-301. [CrossRef]

50. Allen, R.; Pereira, L.S.; Raes, D.; Smith, M. Crop Evapotranspiration: Guidelines for Computing Crop Water Requirements; FAO Irrigation and Drainage Paper 56; United Nations FAO: Rome, Italy, 1998.

51. Ribas, A.; Llausàs, A.; Saurí, D.; Roset, D. Perception et évaluation sociale de l'irrigation traditionnelle dans le Bas Ter (Bas Ampurdan, Catalogne). In De l'eau Agricole à l'eau Environnementale. Résistance et Adaptation aux Nouveaux Enjeux de Partage de l'eau en Méditerranée; Aspe, C., Ed.; Update Sciences \& Technologies: Paris, France, 2012; pp. 199-208. (In French)

52. Ribas, A.; Llausàs, A.; Saurí, D.; Roset, D. El paper dels recs de Sentmenat i del Molí de Pals en la configuració de la plana agrícola del Baix Ter. Estudis d'Història Agràr. 2012, 23, 319-334. (In Catalan)

53. Pujol, J.; Berbel, J.; Ramírez de Cartagena, F.; Viaggi, D.; Raggi, M. Evaluation of markets for irrigation water in the internal river basins of Catalonia, Spain. Span. J. Agric. Res. 2006, 4, 3-16. [CrossRef]

54. Arbat, G.; Puig-Bargués, J.; Duran-Ros, M.; Barragán, J.; Ramírez de Cartagena, F. Irrigation performance and gross water productivity in furrow-irrigated ornamental tree production. Span. J. Agric. Res. 2011, 9 , 627-640. [CrossRef]

55. Cots, L.L.; Barragán, J.; Monserrat, J. Conveyance Efficiency in the Urgell Canals (Lleida, Spain); Congress on Industrial \& Agricultural Canals: Lleida, Spain, 2014.

56. Cots, L.L.; Monserrat, J.; Barragán, J. El regadiu a Lleida. Resultats de diverses avaluacions a la zona regable dels canals d'Urgell (Lleida). Quad. Agrar. 2014, 36, 23-50. (In Catalan)

57. Rijo, M.; Almeida, A.B. Performance of an automatic upstream controlled irrigation system: Conveyance efficiencies. Irrig. Drain. Syst. 1993, 7, 161-172. [CrossRef]

58. Koech, R.K.; Smith, R.J.; Gillies, M.H. A real-time optimisation system for automation of furrow irrigation. Irrig. Sci. 2014, 32, 319-327. [CrossRef]

59. Giannakis, E.; Bruggeman, A.; Djuma, H.; Kozyra, J.; Hammer, J. Water pricing and irrigation across Europe: Opportunities and constraints for adopting irrigation scheduling decision support systems. Water Sci. Technol. Water Supply 2016, 16, 245-252. [CrossRef]

60. Knox, J.W.; Kay, M.G.; Weatherhead, E.K. Water regulation, crop production and agricultural water management-Understanding farmer perspectives on irrigation efficiency. Agric. Water Manag. 2012, 108, 3-8. [CrossRef]

61. Giannakis, E.; Bruggeman, A. The highly variable economic performance of European agriculture. Land Use Policy 2015, 45, 26-35. [CrossRef]

62. Lichtenberg, E.; Majsztrik, J.; Saavoss, M. Grower demand for sensor-controlled irrigation. Water Resour. Res. 2015, 51, 341-358. [CrossRef]

63. Genius, M.; Koundouri, P.; Nauges, C.; Tzouvelekas, V. Information transmission in irrigation technology adoption and diffusion: Social learning, extension services, and spatial effects. Am. J. Agric. Econ. 2014, 96, 328-344. [CrossRef] 
64. Nam, W.H.; Hong, E.M.; Choi, J.Y. Assessment of water delivery efficiency in irrigation canals using performance indicators. Irrig. Sci. 2016, 34, 129-143. [CrossRef]

65. Hsiao, T.C.; Steduto, P.; Fereres, E. A systematic and quantitative approach to improve water use efficiency in agriculture. Irrig. Sci. 2007, 25, 209-231. [CrossRef]

66. Molden, D.J.; Gates, T.K. Performance measures for evaluation of irrigation-water-delivery systems. J. Irrig. Drain. Eng. 1990, 116, 804-823. [CrossRef]

67. Korkmaz, N.; Avci, M.; Unal, H.B.; Asik, S.; Gunduz, M. Evaluation of the water delivery performance of the Menemen Left Bank irrigation system using variables measured on-site. J. Irrig. Drain. Eng. 2009, 135, 633-642. [CrossRef]

68. Aly, A.M.; Kitamura, Y.; Shimizu, K. Assessment of irrigation practices at the tertiary canal level in an improved system-A case study of Wasat area, the Nile Delta. Paddy Water Environ. 2013, 11, 445-454.

69. Vandersypen, K.; Bengaly, K.; Keita, A.C.T.; Sidibe, S.; Raes, D.; Jamin, J.Y. Irrigation performance at tertiary level in the rice schemes of the Office du Niger (Mali): Adequate water delivery through over-supply. Agric. Water Manag. 2006, 83, 144-152. [CrossRef]

70. Lecina, S.; Neale, C.M.U.; Merkley, G.P.; Dos Santos, C.A.C. Irrigation evaluation based on performance analysis and water accounting at the Bear River irrigation project (USA). Agric. Water Manag. 2011, 98, 1349-1363. [CrossRef]

71. Masseroni, D.; Facchi, A.; Depoli, E.V.; Renga, F.M.; Gandolfi, C. Irrig-OH: An Open-Hardware Device for Soil Water Potential Monitoring and Irrigation Management. Irrig. Drain. 2016, 65, 750-761. [CrossRef]

72. Di Fidio, M.; Gandolfi, C. Flow velocity measurement in Italy between Renaissance and Risorgimento. J. Hydraul. Res. 2011, 49, 578-585. [CrossRef]

73. Chiaradia, E.A.; Facchi, A.; Masseroni, D.; Ferrari, D.; Bischetti, G.B.; Gharsallah, O.; Gandolfi, C. An integrated, multisensor system for the continuous monitoring of water dynamics in rice fields under different irrigation regimes. Environ. Monit. Assess. 2015, 187, 1-17. [CrossRef] [PubMed]

74. Lüthi, B.; Philippe, T.; Pena-Haro, S. Mobile device app for small open-channel flow measurement. In Proceedings of the 7th International Congress on Environmental Modelling and Software (iEMSs' 14), San Diego, CA, USA, 15-19 June 2014; Volume 1, pp. 283-287.

75. Kim, H.D.; Kim, J.T.; Nam, W.H.; Kim, S.J.; Choi, J.Y.; Koh, B.S. Irrigation Canal Network Flow Analysis by a Hydraulic Model. Irrig. Drain. 2016, 65, 57-65. [CrossRef]

76. Giuliani, M.; Li, Y.; Castelletti, A.; Gandolfi, C. A coupled human-natural systems analysis of irrigated agriculture under changing climate. Water Resour. Res. 2016, 52. [CrossRef]

77. Masseroni, D.; Uddin, J.; Tyrrell, R.; Mareels, I.; Gandolfi, C.; Facchi, A. Towards a smart automated surface irrigation management in rice-growing areas in Italy. J. Agric. Eng. 2016. [CrossRef]

78. Oakes, T.; Ciavarella, G.; Halm, R. Critical Success Factors for Large Scale Automation Experiences from 10,000 Gates. 2010. Available online: https://dspace.library.colostate.edu/bitstream/handle/10217/79244/ 120_2010_CO_USCID_Oakes.pdf?sequence=20\&isAllowed=y (accessed on 30 March 2010).

79. Leibundgut, C. Historical meadow irrigation in Europe-a basis for agricultural development. IAHS Publ. 2004, 286, 77-87.

80. Leibundgut, C.; Kohn, I. European traditional irrigation in transition part II: Traditional irrigation in our Time-decline, rediscovery and restoration perspectives. Irrig. Drain. 2014, 63, 294-314. [CrossRef]

81. Garrod, B.; Wornell, R.; Youell, R. Re-conceptualising rural resources as countryside capital: The case of rural tourism. J. Rural Stud. 2006, 22, 117-128. [CrossRef]

82. Asah, S.T.; Guerry, A.D.; Blahna, D.J.; Lawler, J.J. Perception, acquisition and use of ecosystem services: Human behavior, and ecosystem management and policy implications. Ecosyst. Serv. 2014, 10, 180-186. [CrossRef]

83. Page, G.; Bellotti, G. Farmers value on-farm ecosystem services as important, but what are the impediments to participation in PES schemes? Sci. Total Environ. 2015, 515-516, 12-19. [CrossRef] [PubMed]

84. Liquete, C.; Cid, N.; Lanzanova, D.; Grizzetti, B.; Reynaud, A. Perspectives on the link between ecosystem services and biodiversity: The assessment of the nursery function. Ecol. Indic. 2016, 63, 249-257. [CrossRef]

85. Van den Dries, A. The Art of Irrigation. The Development, Stagnation and Redesign of Farmer-Managed Irrigation Systems in Northern Portugal. Ph.D. Thesis, Wageningen Universiteit, Wageningen, The Netherlands, 15 October 2002. 
86. Van den Dries, A.; Portela, J. Institutional support for the development of farmer managed irrigation. In Strengthening Endogenous Development Patterns in European Agriculture; van der Ploeg, J., Ed.; Options Mediterraneennes, Série A. Séminaires Méditerranéens 23; Centre International de Hautes Etudes Agronomiques Méditerranéennes (CIHEAM): Paris, France, 1993.

87. Bodin, O.; Crona, B.I. The role of social networks in natural resource governance: What relational patterns make a difference? Glob. Environ. Chang. 2009, 19, 366-374. [CrossRef]

88. Jones, A.M.; Crook, D.S. Traditional irrigation in dryland Switzerland. In The Archaeology of Drylands: Living on the Margins; Barker, G., Gilbertson, D., Eds.; Routledge: London, UK, 2000.

89. Selman, P. Community participation in the planning and management of cultural landscape. J. Environ. Plan. Manag. 2004, 47, 365-392. [CrossRef]

90. Guillet, D. Rethinking irrigation efficiency: Chain irrigation in northwestern Spain. Hum. Ecol. 2006, 34, 305-329. [CrossRef]

91. Smith, L.C.; Pavelsky, T.M.; MacDonald, G.M.; Shiklomanov, A.I.; Lammers, R.B. Rising minimum daily flows in northern Eurasian rivers: A growing influence of groundwater in the high-latitude hydrologic cycle. J. Geophys. Res. Biogeosci. 2007, 112. [CrossRef]

92. Pulido-Bosch, A.; Ben Sbih, Y.B. Centuries of artificial recharge on the southern edge of the Sierra Nevada (Granada, Spain). Environ. Geol. 1995, 26, 57-63. [CrossRef]

93. Séraphin, P.; Vallet-Coulomb, C.; Gonçalvès, J. Partitioning groundwater recharge between rainfall infiltration and irrigation return flow using stable isotopes: The Crau aquifer. J. Hydrol. 2016, in press.

94. Directive, N. Council Directive 91/676/EEC of 12 December 1991 concerning the protection of waters against pollution caused by nitrates from agricultural sources. Off. J. 1991, 375, 1-8.

95. Masseroni, D.; Chiaradia, E.A.; Anglese, P.; Callerio, M.; Burzilleri, L.; Fossati, M.; Bischetti, G.B.; Gandolfi, C. Progetto Flood-Hide: La Rete Rurale a Supporto Della Laminazione Dei Deflussi Di Piena Provenienti Dai Territori Urbanizzati. In Proceedings of the XXXV Convegno Nazionale di Idraulica e Costruzioni Idrauliche Bologna, Bologna, Italy, 14-16 September 2016. (In Italian)

96. Mukherji, A. The energy-irrigation nexus and its impact on groundwater markets in eastern Indo-Gangetic basin: Evidence from West Bengal, India. Energy Policy 2007, 35, 6413-6430. [CrossRef]

(C) 2017 by the authors; licensee MDPI, Basel, Switzerland. This article is an open access article distributed under the terms and conditions of the Creative Commons Attribution (CC-BY) license (http://creativecommons.org/licenses/by/4.0/). 